\title{
Kinerja Jaringan Komunikasi Nirkabel Berbasis Xbee pada Topologi Bus, Star dan Mesh
}

\section{FAQIH ROFII, FACHRUDIN HUNAINI, SHOFIE SHOLAWATI}

\author{
Universitas Widyagama Malang \\ Email: faqih@widyagama.ac.id
}

Received 14 Agustus 2018 | Revised 29 Agustus 2018 | Accepted 30 September 2018

\begin{abstract}
ABSTRAK
Jaringan sensor nirkabel merupakan perangkat komunikasi yang memiliki kesederhanaan pada prosesor, konsumsi daya rendah, antena dan beberepa detektor. Biaya yang rendah dan fleksibel sangat cocok digunakan untuk berbagai aplikasi monitoring di industri dan lingkungan baik indoor maupun outdoor. Salah satu perangkat transceiver yang banyak digunakan pada saat ini adalah Xbee. Perangkat ini dapat dikonfigurasi sebagai coordinator, router maupun end-device sesuai dengan topologi jaringan yang dibangun. Penelitian ini bertujuan untuk menganalisis kinerja Xbee dengan parameter RSSI, troughput dan delay dengan topologi bus, star, mesh dan hybrid pada indoor dan outdoor. Pengukuran dilakukan dalam rentang jarak 0-40 meter pada kondisi indoor dan 0-120 meter pada kondisi outdoor. Berdasarkan hasil pengujian pada indoor dan outdoor, nilai optimum diperoleh pada topologi mesh dengan delay dan packet loss terkecil sebesar 2,7 detik dan 0,5 paket untuk indoor serta 3,41 detik dan 0,33 paket untuk outdoor.
\end{abstract}

Kata kunci: jaringan sensor nirkabel, xbee, topologi bus, star dan mesh

\begin{abstract}
Wireless sensor networks are communication devices that have simplicity in the processor, low power consumption, antennas and some detectors. Low and flexible costs are suitable for various monitoring applications in the industry and environment both indoors and outdoors. One of the transceiver devices that is widely used today is Xbee. This device can be configured as a coordinator, router or end-device in accordance with the network topology that is built. This study aims to analyze the performance of Xbee with RSSI parameters, throughput and delay with bus, star, mesh and hybrid topologies in indoor and outdoor. Measurements are carried out in the range of 0-40 meters in indoor conditions and 0-120 meters in outdoor conditions. Based on the results of testing on indoor and outdoor, the optimum value was obtained in mesh topology with the smallest delay and packet loss of 2.7 seconds and 0.5 packets for indoor and 3.41 seconds and 0.33 packets for outdoor.
\end{abstract}

Keywords: wireless sensor network, xbee, bus, star and mesh network topology 


\section{PENDAHULUAN}

Jaringan sensor nirkabel atau wireless sensor network (WSN) terdiri dari node-node sensor yang memiliki prosesor sederhana, konsumsi daya rendah, antena dan beberepa detektor. Node sensor mempunyai kemampuan untuk mengambil, memproses dan mengirimkan data melalui nodeyang berdekatan menuju ke server (Dener \& Bostancıoğlu, 2015). Biaya yang rendah dan fleksibel di dalam penggunaan, menjadikan WSN cocok digunakan untuk berbagai aplikasi monitoring di industri dan lingkungan baik indoor (Bhasworo, Rofii, \& Hunaini, 2018) maupun outdoor (Yulianto, Jazi Eko, Kirbani, \& others, 2012). Bagian penting dari WSN adalah perangkat pengirim dan penerima data informasi (transceiver) secara nirkabel. Pemilihan perangkat tranceiver yang tepat akan menentukan kualitas komunikasi WSN. Fajriansyah, dkk. telah mengevaluasi dua modul transceiver yaitu XBee Pro dan nRFf24L01+ dengan maksud untuk menentukan modul transceiver mana yang tepat digunakan untuk WSN dengan mengirimkan data dalam bentuk karakter ASCII/ bytes secara kontinyu maupun sekuensial melalui komunikasi serial UART. Pada penelitian tersebut hanya mengetahui Round Time Trip dan tidak menggunakan bentuk dari topologi jaringan yang dibangun (Fajriansyah, Ichwan, \& Susana, 2016).

Simulasi kinerja pada Wireless Personal Area Network (WPAN) Zegbee dilakukan oleh Thamrin dengan menggunakan software Network Simulator 2 (NS-2) pada topologi mesh, star dan cluster tree. Indikator dari analisis kinerja didasarkan pada throughput, delay dan packet delivery ratio (PDR). Kinerja jaringan diamati melalui lima skenario dengan melakukan variasi jumlah node. Masing-masing skenario dikirimkan paket data 50. Jarak masing-masing node adalah 10 meter. Simulasi yang dilakukan menghasilkan nilai yang berbeda pada tiap skenario (Thamrin, 2014). Wahyudi, dkk. menguji parameter kinerja WPAN dengan teknologi mesh untuk menghasilkan jumlah perangkat WSN yang optimal. Pengujian dilakukan dengan simulasi untuk mengukur parameter throughput, traffic (sent, receive dan drop), delay, dan jumlah hop. Hasil pengujian menunjukkan bahwa kinerja WPAN dengan standar Zigbee topologi mesh menghasilkan nilai optimal pada saat jumlah perangkat WSN maksimum berjumlah 20 perangkat (Wahyudi, Hidayat, \& Sumaryono, 2012).

Modul Xbee banyak digunakan sebagai transceiver dalam berbagai implementasi WSN, karena memungkinkan untuk pengaturan routing dan topologi jaringan. Mukhtar, K. dalam penelitiannya menggunakan Xbee untuk mendesain autonomous routing pada WSN untuk pengukuran suhu dan intensitas cahaya. Sistem telah diuji menggunakan 6 buah sensor node dan satu sink node. Dari 10 topologi ditemukan waktu konfigurasi routing tercepat sebesar 14 detik, namun belum mempertimbangkan parameter RRSI, throughput dan packet loss (Mukhtar \& Sumiharto, 2012). Beberapa penelitian sebelumnya, implementasi dan pengujian Xbee pada WSN belum menggambarkan secara menyeluruh pada berbagai topologi jaringan, sebagaimana yang dilakukan oleh Piyare pengukuran kinerja hanya pada topologi point to point (Piyare \& Lee, 2013). Penelitian ini bertujuan untuk menganalisis kinerja Xbee sebagai transceiver dengan topologi bus, star, mesh dan hybrid. Parameter yang akan diuji antara lain jarak jangkauan maksimum, RSSI, throughput, dan delay. Nilai dan data yang didapat dari penelitian ini dapat menjadi dasar untuk implementasi jaringan sensor nirkabel yang membutuhkan berbagai topologi jaringan dengan mempertimbangkan kuat sinyal, troughput maupun delay seperti pemantauan lingkungan, hewan maupun pelacakan objek bergerak. 
Hubungan geometris antara unsur-unsur dasar penyusun jaringan, berupa node, link, dan station dalam jaringan komputer/telekomunikasi dinyatakan sebagai topologi jaringan. Setiap jenis topologi memiliki kelebihan dan kekurangan. Pada penelitian ini, topologi jaringan yang dianalisis adalah bus, star, mesh dan hybrid. Topologi bus adalah jenis topologi yang menggunakan saluran tunggal sebagai media transmisinya yang menghubungkan semua client dengan server. Keuntungan topologi bus adalah layout dan skema media transmisi yang digunakan sangat sederhana sehingga saat akan dilakukan penambahan client baru untuk keperluan pengembangan, penyambungan kabel jaringan dapat dilakukan dengan mudah. Kerugian topologi bus adalah jika terjadi gangguan dalam hubungan kabel dimana saja di dalam jaringan, maka seluruh jaringan akan mengalami gangguan.

Jenis topologi dimana setiap client dihubungkan secara langsung ke server atau hub/switch disebut sebagai topologi bintang (star). Topologi ini tahan terhadap lalu lintas yang tinggi dan cukup aman namun sangat bergantung kepada fungsionalitas hub pusat. Pada topologi mesh menerapkan hubungan antar node secara penuh. Komunikasi berjalan relatif cepat dan biasanya digunakan untuk membangun jaringan dengan skala yang tidak terlalu besar. Kelebihan topologi mesh adalah memiliki hubungan dedicated link yang menjamin data langsung dikirim ke komputer tujuan tanpa harus melalui komputer lain sehingga data yang mengalir dapat berjalan lebih cepat. Namun topologi mesh membutuhkan banyak kabel dan port I/O sehingga sulit untuk melakukan instalasi dan konfigurasi karena setiap komputer harus terkoneksi secara langsung (Supriyadi \& Gartina, 2007).

Kinerja jaringan komunikasi nirkabel dapat diukur berdasarkan beberapa parameter, antara lain : jarak jangkauan komunikasi, Received Signal Strength Indicator (RSSI), troughput dan delay. RSSI adalah sebuah ukuran kekuatan sinyal radio yang diterima oleh receiver. Faktor jarak antara pemancar dan penerima sangat menentukan besarnya RSSI (Puspitasari, 2014) yang dinyatakan dalam Persamaan (1).

$$
R S S I=P_{T}-P_{L}-10 \log n d+X_{\sigma}(\mathrm{dBm})
$$

dimana $P_{T}$ adalah daya pancar, $P_{L}$ adalah rugi lintasan, $\mathrm{n}$ adalah eksponen rugi lintasan, $\mathrm{d}$ adalah jarak dan $X_{\sigma}$ adalah variabel acak gaussian dari lingkungan propagasi. Parameter throughput dapat dicari dengan menghitung laju rata-rata dari paket data yang berhasil dikirim melalui kanal komunikasi. Throughput dapat juga dihitung sebagai jumlah paket data yang diterima setiap detik, dinyatakan dengan Persamaan (2).

$$
\text { Throughput }=\frac{\text { Besa Data }(\mathrm{Kb})}{\text { Waktu Tempuh }(s)}
$$

Sedangkan delay merupakan waktu tunda paket data tiba di client atau host sampai selesai ditransmisikan. Delay transmisi dapat dihitung dengan Persamaan (3) dan (4).

$$
\text { Delay total }=\text { Time Received }(s)-\text { Time Sent }(s)
$$

delay paket yang diterima dari server menuju client adalah :

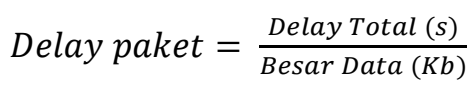

Jumlah packet loss dari pengirim ke penerima dinyatakan sebagai :

$$
\sum \text { Packet Loss }=\sum \text { Packet dikirim }-\sum \text { Packet diterima }
$$




\section{METODE PENELITIAN}

Perangkat yang digunakan untuk penelitian ini adalah Xbee S2, catu daya DC dan software XCTU. Xbee S2 adalah modul transceiver radio yang diproduksi oleh DIGI International yang beroperasi pada frekuensi 2,4 GHz, protokol komunikasi Zigbee dan laju data sebesar 250 kbps. Xbee S2 mendukung mesh networking, sebab setiap modul Xbee S2 dapat ditentukan perannya dalam suatu topologi jaringan yang hendak kita bangun. Peran yang dimaksud adalah sebagai Coordinator, Router maupun End-Device.

Untuk melakukan pengaturan modul Xbee dan konfigurasi jaringan maka dibutuhkan software XCTU, yaitu sebuah aplikasi yang disediakan oleh DIGI, dimana program ini dirancang untuk berinteraksi dengan Xbee. Pada software ini, user dapat melakukan update firmware Xbee dari coordinator menjadi router dan atau end device, begitu pun sebaliknya. Perangkat lunak ini mudah digunakan dan memungkinkan untuk menguji Xbee di lingkungan sebenarnya menggunakan komputer, mikrokontoller dan sejumlah sensor.

Untuk merancang jaringan sesuai dengan topologi yang akan diuji, maka pada penelitian ini digunakan dua buah komputer sebagai server dan client, serta 5 buah model Xbee2 sebagai modul transceiver. Masing-masing modul Xbee2 dikonfigurasi sesuai dengan perannya yaitu sebagai coordinator, router dan end-device. Gambar 1 sampai dengan 4, merupakan rancangan topologi jaringan bus, star, mesh dan hybrid. Gambar 1 adalah blok diagram rancangan jaringan Xbee dengan topologi bus. PC 1 dikonfigurasi sebagai server sedangkan modul xbee1 sebagai coordinator, modul xbee 2 dan 3 sebagai router, modul xbee 4 sebagai end device, sedangkan PC 2 sebagai client.

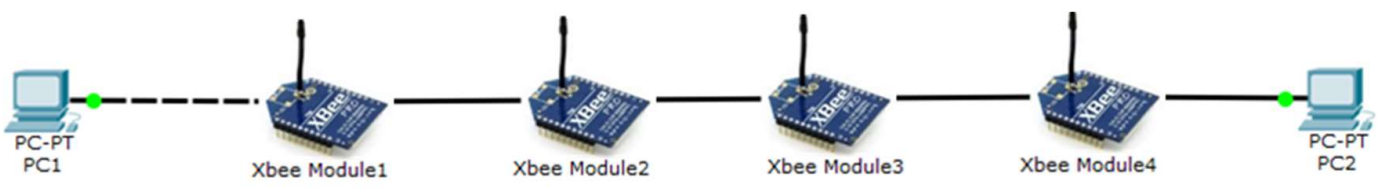

Gambar 1. Rancangan Topologi Bus

Gambar 2 adalah blok diagram rancangan jaringan Xbee dengan topologi star. PC 1 dikonfigurasi sebagai server yang dihubungkan langsung dengan sebuah modul Xbee yaitu modul Xbee 1 yang dikonfigurasi sebagai coordinator. Modul Xbee dari server ini akan terhubung dengan 4 buah modul Xbee sebagai end device, sedangkan PC 2 dalam rancangan ini sebagai client. PC 2 berperan sebagai perangkat yang mengukur parameter dari salah satu end device yang ada dalam topologi star ini.

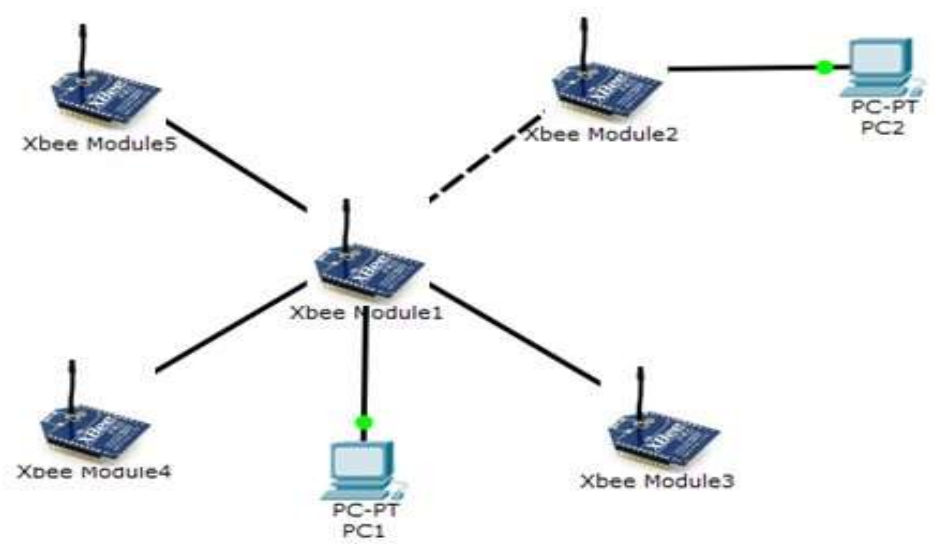

Gambar 2. Rancangan Topologi Star 
Gambar 3 adalah blok diagram rancangan jaringan Xbee menggunakan topologi mesh. Dalam topologi ini, masing-masing modul Xbee terhubung dengan yang lainnya. PC 1 dan PC 2 dapat berperan sebagai server maupun client dengan dihubungkan langsung melalui modul Xbee 0 dan modul Xbee 1.

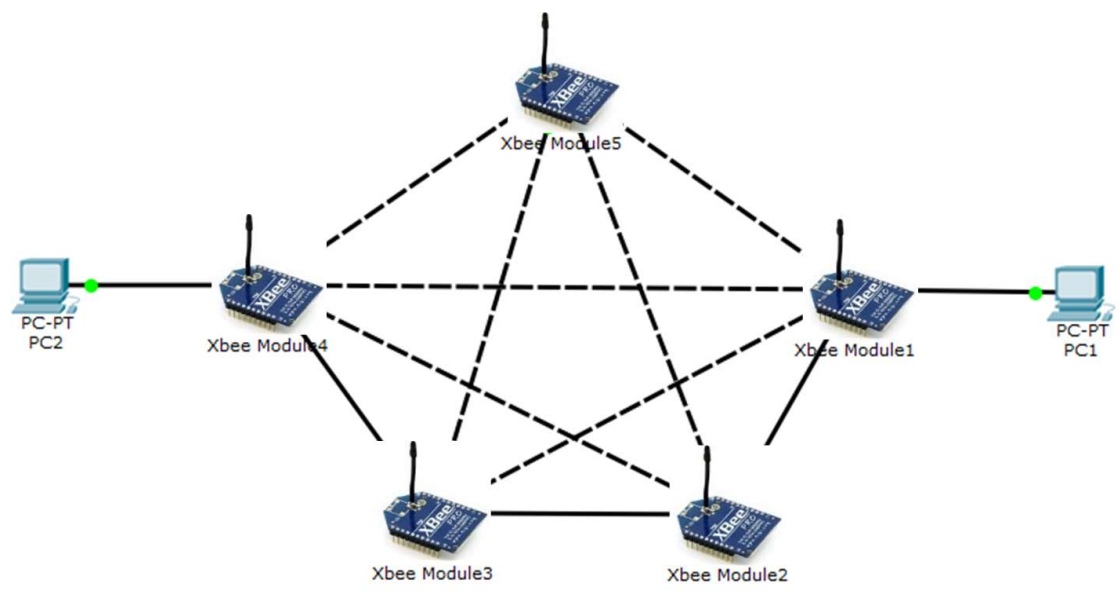

Gambar 3. Rancangan Topologi Mesh

Gambar 4 merupakan blok diagram rancangan jaringan Xbee menggunakan topologi hybrid. Pada rancangan ini terdapat 2 buah komputer dan 9 buah modul Xbee. Modul Xbee 1, 2 dan 3 membentuk topologi bus, modul Xbee 3, 4, 5 dan 6 membentuk topologi star dimana modul Xbee 3 berfungsi sebagai coordinator. Selanjutnya modul Xbee 3 terhubung ke modul Xbee7 yang merupakan bagian dari jaringan lain dengan topologi mesh, jaringan ini terdiri dari modul Xbee 7, 8, 9 dan 10. PC 1 berfungsi sebagai server, sedangkan PC 2 berfungsi sebagai client yang digunakan untuk mengukur parameter kinerja jaringan dari topologi hybrid yang telah terbentuk.

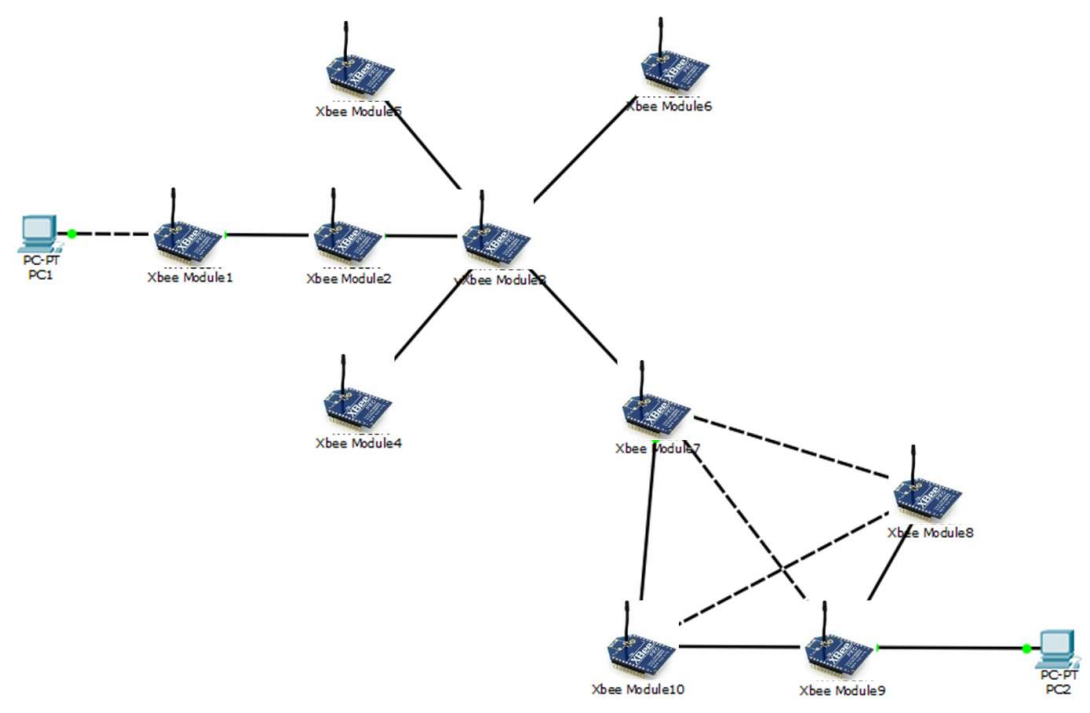

Gambar 4. Rancangan Topologi Hybrid 
Pengaturan parameter modul Xbee di XCTU sebagai coordinator, routerdan end device adalah sebagaimana pada Tabel 1.

Tabel 1. Pengaturan Parameter Coordinator, Routerdan End Device

\begin{tabular}{|l|l|l|}
\hline \multicolumn{1}{|c|}{ Parameter } & \multicolumn{1}{c|}{ Coordinator } & \multicolumn{1}{c|}{ Router dan End Device } \\
\hline PAN ID & 1234 & 1234 \\
\hline Scan Channels & A & A \\
\hline Destination Address High & 0 & Sesuai alamat MAC Xbee \\
\hline Destination Address Low & FFF & Sesuai Alamat MAC Coordinator \\
\hline
\end{tabular}

Mode komunikasi dapat diatur menjadi mode AT atau API. Mode AT adalah mode transparan, dalam mode ini data yang dikirim dari coordinatorakan segera dikirim ke modul remote dalam jaringan yang sama, dengan catatan alamat Xbee tersebut telah diidentifikasi dan dikenali oleh coordinator. Format paket data tidak diperlukan, karena mode AT lebih sederhana dan sistematis dalam hal mengirim data dari pemancar menuju penerima. Mode AT sangat cocok diimplementasikan dalam topologi terpusat/star. Selain sistemnya yang sederhana, transmisi mode AT ini mudah dan cepat. Dalam mode API atau Application Programming Interface data harus mengikuti struktur frame berupa formasi data (payload) dan alamat Xbee tujuan. Mode ini umumnya digunakan untuk jaringan yang lebih besar, dengan melibatkan node yang saling terhubung satu sama lain. Bentuk formasi data pada mode API bersifat editable, karena setiap data dibuat dalam bentuk frame. Mode ini sesuai untuk digunakan dalam topologi mesh, dan hybrid, dimana setiap node dapat melakukan interface satu sama lain dengan alamat tujuan yang lebih fleksibel. Mode ini juga dapat digunakan pada topologi bus sebagai pengganti kabel dan routing system.

Pada penelitian ini, pengujian ini dilakukan pada dua kondisi, yaitu indoor dan outdoor. Pengujian indoor bertempat di sebuah gedung dengan luas bangunan 56 x 76 meter, sebagaimana ditunjukkan pada Gambar 5.

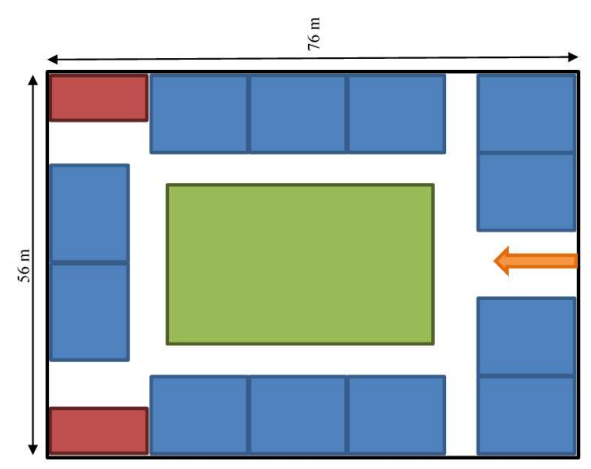

Gambar 5. Sketsa Gedung Pengujian Indoor

Keterangan:

Ruang Sekretariat UKM

Aula/Ruang Rapat Bersama

Toilet

Pintu masuk gedung 
Sedangkan pengujian outdoor dilakukan di jalan terbuka sepanjang 430 meter. Sketsa pengambilan data dapat dilihat pada Gambar 6.

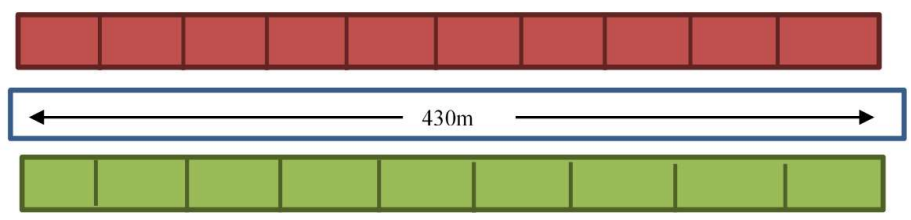

Gambar 6. Sketsa Gedung Pengujian Outdoor

Keterangan:

$\square \square$ Deretan rumah penduduk $\square$ Jalan lokasi pengambilan data

\section{HASIL DAN PEMBAHASAN}

Hasil pengujian dibagi ke dalam dua bagian, yaitu indoor dan outdoor. Parameter yang diuji adalah RSSI sebagai fungsi jarak, troughput dan delay. Hasil pengujian yang telah dilakukan adalah :

1) Hasil Pengukuran RSSI

Data pada Table 1 adalah hasil pengukuran RSSI dalam dBm untuk kondisi indoor dan outdoor.

Tabel 2. Hasil Pengukuran RSSI pada Kondisi Indoor dan Outdoor

\begin{tabular}{|c|c|c|c|c|c|c|c|c|c|}
\hline \multirow{3}{*}{ Jarak (m) } & \multicolumn{4}{|c|}{ RSSI Indoor (dBm) } & \multirow{3}{*}{ Jarak (m) } & \multicolumn{4}{|c|}{ RSSI Outdoor (dBm) } \\
\hline & \multicolumn{4}{|c|}{ Topologi } & & \multicolumn{4}{|c|}{ Topologi } \\
\hline & Bus & Star & Mesh & Hybrid & & Bus & Star & Mesh & Hybrid \\
\hline 5 & -35.4 & -30.4 & -66.4 & -29.4 & 10 & -26.7 & -33.7 & -28.7 & -29.7 \\
\hline 10 & -40.5 & -35.5 & -74.5 & -44.5 & 20 & -33 & -50 & -30 & -30 \\
\hline 15 & -62.6 & -42.6 & -71.6 & -47.6 & 30 & -35.13 & -55.1 & -39.1 & -39.1 \\
\hline 20 & -70.7 & -55.7 & -77.7 & -54.7 & 50 & -45.3 & -67.3 & -58.3 & -44.3 \\
\hline 25 & -72.8 & -69.8 & -81.8 & -70.8 & 80 & -68.4 & -75.4 & -84.4 & -79.46 \\
\hline 30 & -74.8 & -75.8 & -89.9 & -76.8 & 100 & -75.5 & -86.5 & -88.53 & -84.5 \\
\hline 35 & -82.9 & -84.9 & -90.9 & -79.9 & 110 & -90.5 & -90.5 & -89.56 & -87.5 \\
\hline 40 & -88.9 & -92.9 & -92.9 & -87.9 & 120 & -86.5 & -93.5 & -91.5 & -89.5 \\
\hline
\end{tabular}



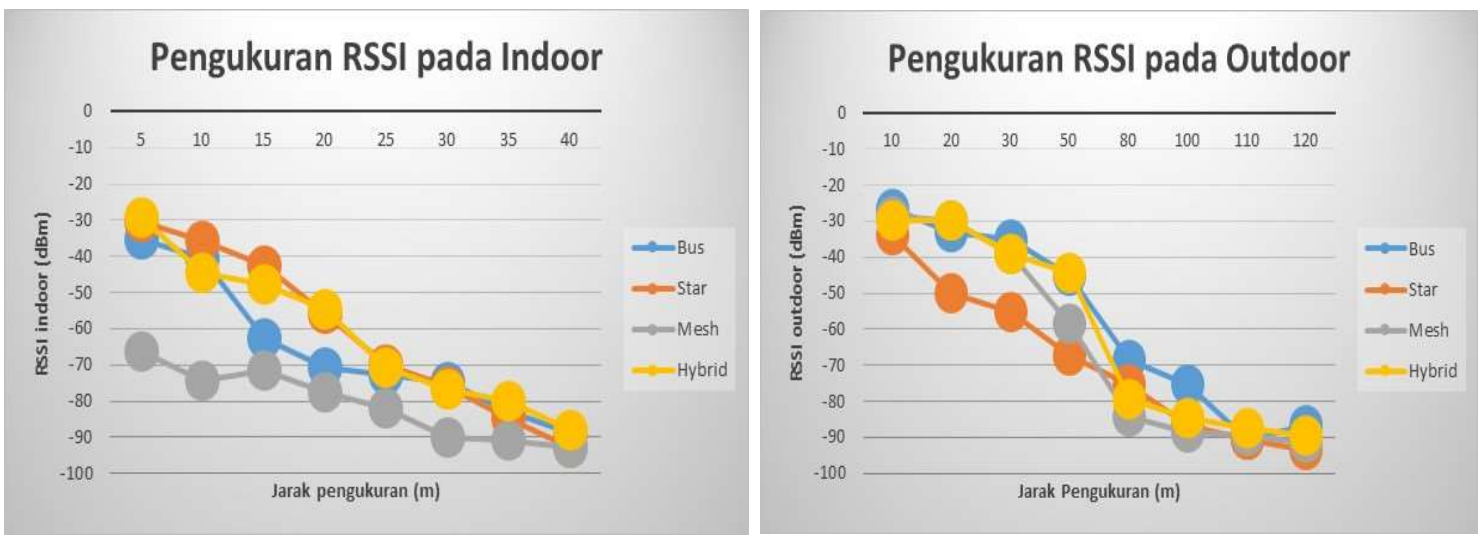

Gambar 7. Grafik Hasil Pengujuan RRSI (dBm) pada Kondisi Indoor dan Outdoor

2) Hasil Pengukuran Throughput

Data pada Tabel 2 adalah hasil pengukuran troughput dalam kbps untuk kondisi indoor dan outdoor.

Tabel 3. Hasil Pengukuran Troughput pada Kondisi Indoor dan Outdoor

\begin{tabular}{|c|c|c|c|c|c|c|c|c|c|}
\hline \multirow{3}{*}{$\begin{array}{c}\text { Jarak } \\
(\mathbf{m})\end{array}$} & \multirow{2}{*}{\multicolumn{4}{|c|}{$\begin{array}{c}\text { Throughput Indoor (kbps) } \\
\text { Topologi }\end{array}$}} & \multirow{3}{*}{$\begin{array}{c}\text { Jarak } \\
(\mathbf{m})\end{array}$} & \multirow{2}{*}{\multicolumn{4}{|c|}{$\begin{array}{c}\text { Throughput Outdoor (kbps) } \\
\text { Topologi }\end{array}$}} \\
\hline & & & & & & & & & \\
\hline & Bus & Star & Mesh & Hybrid & & Bus & Star & Mesh & Hybrid \\
\hline 5 & 0.46 & 0.17 & 0.075 & 0.091 & 10 & 0.09 & 0.09 & 0.17 & 0.091 \\
\hline 10 & 0.46 & 0.17 & 0.165 & 0.091 & 20 & 0.1 & 0.09 & 0.17 & 0.091 \\
\hline 15 & 0.28 & 0.17 & 0.115 & 0.091 & 30 & 0.09 & 0.1 & 0.17 & 0.091 \\
\hline 20 & 0.27 & 0.013 & 0.061 & 0.083 & 50 & 0.09 & 0.1 & 0.17 & 0.091 \\
\hline 25 & 0.26 & 0.014 & 0.084 & 0.041 & 80 & 0.067 & 0.03 & 0.17 & 0.056 \\
\hline 30 & 0.24 & 0.084 & 0.02 & 0.045 & 100 & 0.035 & 0.02 & 0.011 & 0.023 \\
\hline 35 & 0.21 & 0.016 & 0.028 & 0.002 & 110 & 0.023 & 0.034 & 0.005 & 0.017 \\
\hline 40 & 0.05 & 0 & 0.016 & 0.005 & 120 & 0.002 & 0.005 & 0.034 & 0.006 \\
\hline
\end{tabular}
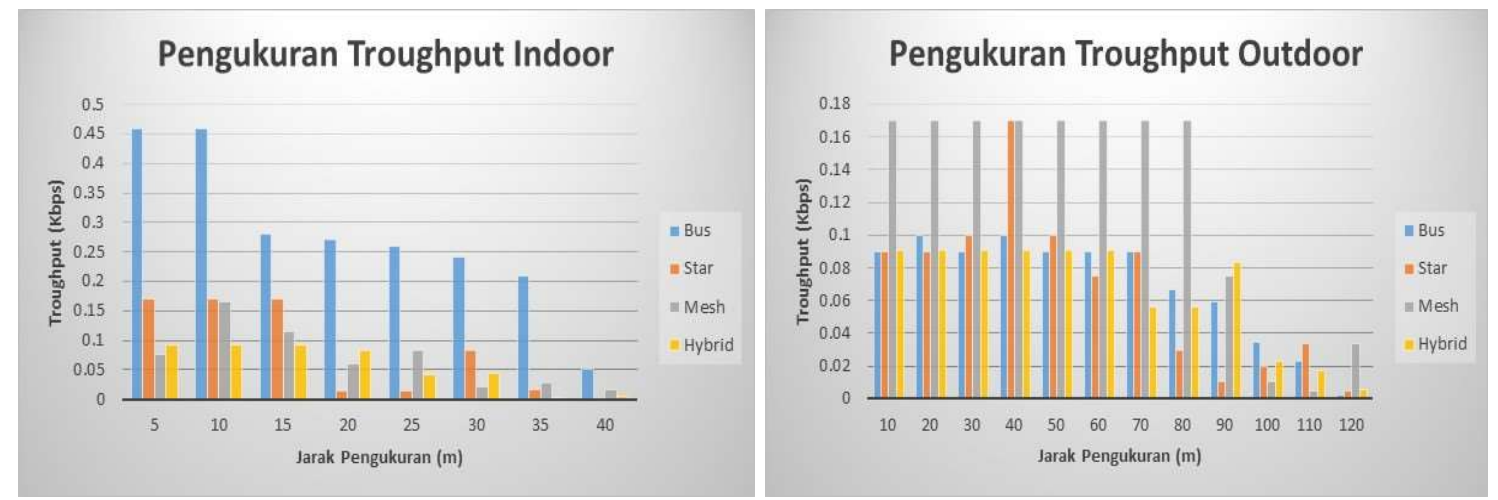

Gambar 8. Grafik Hasil Pengujian Troughput pada Kondisi Indoor dan Outdoor 
3) Hasil Pengukuran Delay

Data pada Tabel 3 adalah hasil pengukuran delay dalam second pada kondisi indoor dan outdoor.

Tabel 4. Hasil Pengukuran Troughput pada Kondisi Indoor Dan Outdoor

\begin{tabular}{|c|c|c|c|c|c|c|c|c|c|}
\hline \multirow{3}{*}{ Jarak } & \multirow{2}{*}{\multicolumn{4}{|c|}{$\begin{array}{c}\text { Delay Indoor (s) } \\
\text { Topologi }\end{array}$}} & \multirow{3}{*}{ Jarak } & \multirow{2}{*}{\multicolumn{4}{|c|}{$\begin{array}{c}\text { Delay Outdoor (s) } \\
\text { Topologi }\end{array}$}} \\
\hline & & & & & & & & & \\
\hline & Bus & Star & Mesh & Hybrid & & Bus & Star & Mesh & Hybrid \\
\hline 5 & 0.4 & 0 & 1 & 1 & 10 & 1 & 0 & 0 & 1 \\
\hline 10 & 0.3 & 0 & 0 & 1 & 20 & 0 & 0 & 0 & 1 \\
\hline 15 & 7 & 0 & 1 & 1 & 30 & 1 & 0 & 0 & 1 \\
\hline 20 & 7.6 & 2.1 & 3 & 2 & 50 & 1 & 0 & 0 & 1 \\
\hline 25 & 8.2 & 4 & 2 & 14 & 80 & 6 & 2 & 0 & 8 \\
\hline 30 & 10.9 & 3 & 4.2 & 9 & 100 & 13 & 4 & 16 & 25 \\
\hline 35 & 14 & 2 & 7 & 10.8 & 110 & 29 & 3 & 21 & 39 \\
\hline 40 & 74 & 48 & 34 & 78 & 120 & 153 & 21 & 3 & 67 \\
\hline
\end{tabular}
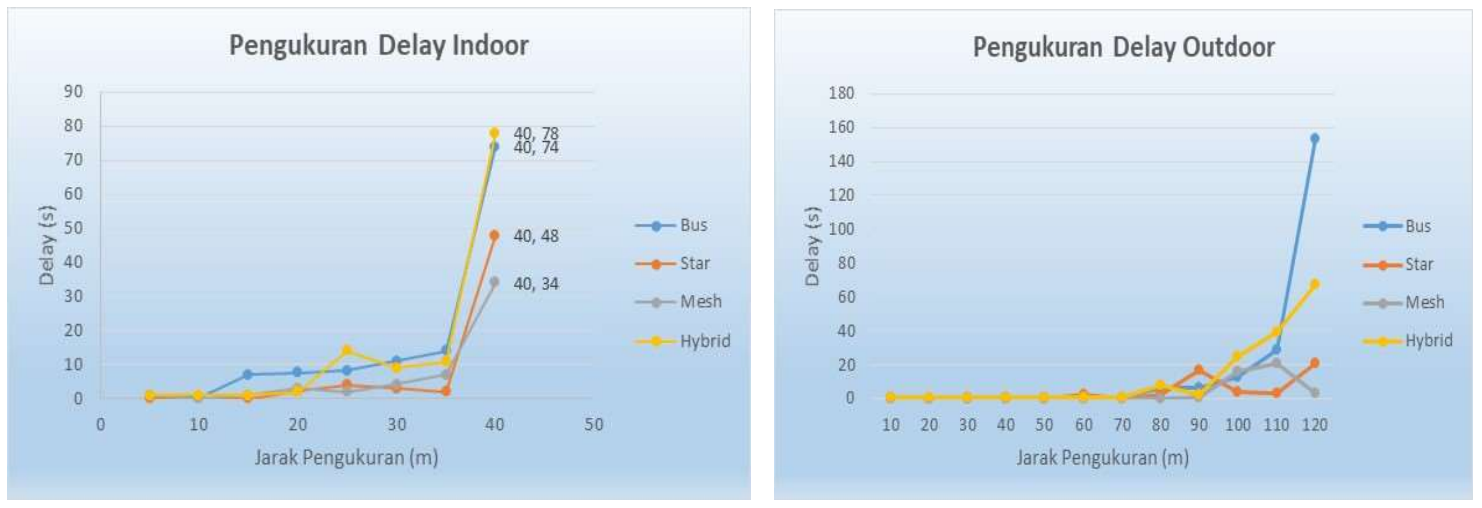

Gambar 9. Grafik Hasil Pengujian Delay pada Kondisi Indoor Dan Outdoor

4) Perbandingan Parameter Kinerja Topologi Jaringan

Tabel 4 dan 5 adalah perbandingan rata-rata nilai hasil pengukuran parameter kinerja untuk semua topologi jaringan pada kondisi indoor dan outdoor.

Tabel 5. Rata-Rata Nilai Hasil Pengukuran pada Kondisi Indoor

\begin{tabular}{|c|c|c|c|c|}
\hline \multirow{2}{*}{ Topologi } & \multicolumn{4}{|c|}{ Rata-rata nilai pengukuran indoor } \\
\cline { 2 - 5 } & RSSI (dBm) & Throughput (kbps) & Delay (s) & $\Sigma$ Packet Loss \\
\hline Bus & $-66,12$ & 0,281 & 15,3 & 6.12 \\
\hline Star & -61 & 0,08 & 9,75 & 5.38 \\
\hline Mesh & $-80,75$ & 0,07 & 2,7 & 0.5 \\
\hline Hybrid & $-61,5$ & 0,056 & 26,75 & 6.25 \\
\hline
\end{tabular}


Tabel 6. Rata-Rata Nilai Hasil Pengukuran pada Kondisi Outdoor

\begin{tabular}{|c|c|c|c|c|}
\hline \multirow{2}{*}{ Topologi } & \multicolumn{4}{|c|}{ Rata-rata nilai pegukuran outdoor } \\
\cline { 2 - 5 } & $\begin{array}{c}\text { RSSI } \\
\text { (dBm) }\end{array}$ & Throughput (kbps) & Delay (s) & $\Sigma$ Packet Loss \\
\hline Bus & $-57,07$ & 0,071 & 17,67 & 3.17 \\
\hline Star & $-69,9$ & 0,07 & 4,17 & 0.92 \\
\hline Mesh & $-66,9$ & 0,12 & 3,41 & 0.33 \\
\hline Hybrid & $-58,49$ & 0,068 & 12,3 & 1.92 \\
\hline
\end{tabular}

Data pada Tabel 2 - 4 didapat melalui pengukuran langsung sesuai dengan konfigurasi dan topologi jaringan dengan menggunakan software XCTU dan perhitungan sesuai dengan Persaman (1) - (4). Tabel 2 adalah hasil pengukuran RSSI pada kondisi indoor dan outdoor yang menunjukkan penurunan RSSI sebagai fungsi dari bertambahnya jarak jangkauan, sebagaimana yang ditunjukkan oleh Gambar 7. RSSI terbesar pada indoor dihasilkan oleh topologi star, sedang outdoor topologi bus. Tabel 3 adalah hasil pengukuran troughput pada kondisi indoor dan outdoor sebagai fungsi jarak. Pada Gambar 8 terlihat nilai troughput terbesar dicapai oleh topologi bus pada kondisi indoor, sedangkan outdoor dicapai oleh mesh. Delay menjadi sangat besar pada saat mencapai jarak 40 meter untuk kondisi indoordan jarak 120 meter untuk kondisi outdoor, sebagaimana ditunjukkan oleh Tabel 4 dan diperlihatkan oleh Gambar 8.

Tabel 5 dan Tabel 6 adalah rata-rata nilai hasil pengukuran indoor dan oudoor. Pada kondisi indoor, RSSI rata-rata terbaik dihasilkan pada topologi star yaitu sebesar $-61 \mathrm{dBm}$ pada rentang jarak 0 - 40 meter. Sedangkan pada kondisi outdoor, topologi bus memiliki rata-rata RSSI terbaik, yaitu sebesar $-57.075 \mathrm{dBm}$ pada rentang jarak $0-120$ meter. Data paket yang dikirim dari pemancar pada penelitian ini sebesar 1,2 kbps, sebagai referensi untuk menghitung besarnya trougphut terhadap lamanya waktu pengiriman. Besarnya throughput maksimal pada kondisi indoor dihasilkan oleh topologi bus dengan troughput rata-rata sebesar $0.281 \mathrm{Kbps}$. Sedangkan pada kondisi outdoor topologi mesh memiliki nilai throughputterbesar, yaitu 0,12 kbps. Sebaliknya throughput terkecil dihasilkan pada topologi hybrid pada kedua kondisi, indoor dan outdoor.

Delay total berpengaruh terhadap sukses tidaknya paket data yang dikirim sampai ke penerima. Delay yang kecil akan mengurangi kemungkinan terjadinya kehilangan paket data, sebaliknya jika delay total besar maka kemungkinan packet loss akan semakin besar. Pada penelitian ini diketahui bahwa topologi mesh memiliki delayterkecil, yaitu hanya 2,7 detik pada kondisi indoor, dan 3,41 detik pada kondisi outdoor. Sedangkan delay terbesar terjadi pada topologi hybrid pada kondisi indoor, dan topologi bus pada kondisi outdoor. Packet Loss didapat dengan cara mengirim sejumlah paket data dari pengirim ke penerima. Jika paket data yang diterima adalah sama dengan jumlah yang dikirim, maka dapat dinyatakan pengiriman berhasil sempurna tanpa ada paket data yang hilang (loss). Sebaliknya jika paket data yang diterima tidak sama dengan jumlah paket data yang dikirim maka terdapat paket yang hilang (packet loss). Besarnya packet loss salah satunya disebabkan oleh jarak dengan delay yang panjang. Packet loss terbesar pada kondisi indoor terjadi pada topologi hybrid, yaitu sebesar 6,2 paket, dan pada kondisi outdoor terjadi pada topologi bus sebesar 3,17 paket. Sedangkan topologi mesh memiliki packet loss terkecil pada kedua kondisi, tercatat sebesar 0,5 paket dan 0,33 paket. 


\section{KESIMPULAN}

Penelitian ini bertujuan untuk menghasilkan analisis kinerja dari Xbee sebagai transceiverpada jaringan nirkabel dengan membandingkan parameter kinerja, berupa RSSI, troughput dan delay untuk topologi jaringan bus, star, mesh dan hybrid pada kondisi indoor dan outdoor. Hasil rata-rata pengukuran indoor pada rentang jarak 0-40 m, didapat bahwa RSSI terbesar pada toplogi star sebesar $-61 \mathrm{dBm}$, troughput terbesar pada topologi bus sebesar 0,281 kbps serta delay dan packet loss terkecil pada topologi mesh yaitu 2,7 detik dan 0,5 paket. Sedangkan hasil rata-rata pengukuran outdoor pada rentang jarak $0-120 \mathrm{~m}$, didapat bahwa RSSI terbesar pada toplogi bus sebesar $-57,07 \mathrm{dBm}$, troughput terbesar pada topologi mesh sebesar 0,12 kbps serta delay dan packet loss terkecil pada topologi mesh sebesar 3,41 detik dan 0,33 paket.

\section{UCAPAN TERIMA KASIH}

Penulis menyampaikan terima kasih kepada Lembaga Penelitian dan Pengabdian Masyarakat Universitas Widyagama Malang yang telah membantu penyelesaian penelitian ini. Terima kasih juga disampaikan kepada Direktorat Riset dan Pengabdian Masyarakat Kementerian Riset, Teknologi dan Pendidikan Tinggi yang telah membiayai penelitian ini.

\section{DAFTAR RUJUKAN}

Bhasworo, G. K., Rofii, F., \& Hunaini, F. (2018). Perancangan Sistem Pemantauan Gas dan Peringatan pada Ruangan melalui Jaringan Nirkabel. Teknik, 38(2), 81-91.

Dener, M., \& Bostancıoğlu, C. (2015). Smart Technologies with Wireless Sensor Networks. Procedia - Social and Behavioral Sciences, 195, 1915-1921. https://doi.org/10.1016/j.sbspro.2015.06.202

Fajriansyah, B., Ichwan, M., \& Susana, R. (2016). Evaluasi Karakteristik XBee Pro dan nRF24L01+ sebagai Transceiver Nirkabel. Jurnal Elkomika, 4(1), 83 - 97.

Mukhtar, K., \& Sumiharto, R. (2012). Konfigurasi Autonomous Routing untuk Jaringan Sensor Nirkabel Berbasis XBee. IJEIS (Indonesian Journal of Electronics and Instrumentation Systems), 2(1), 33-44.

Piyare, R., \& Lee, S. (2013). Performance analysis of XBee ZB module based wireless sensor networks. International Journal of Scientific \& Engineering Research, 4(4), 1615-1621.

Puspitasari, N. F. (2014). Analisis Rssi (Receive Signal Strength Indicator) Terhadap Ketinggian Perangkat Wi-fi Di Lingkungan Indoor. Data Manajemen Dan Teknologi Informasi (DASI), 15(4), 32-38.

Supriyadi, A., \& Gartina, D. (2007). Memilih Topologi Jaringan Dan Hardware Dalam Desain Sebuah Jaringan Komputer. Informatika, 16(2), 1037-1053.

Thamrin, T. (2014). Analisis Kinerja Jaringan Wpan Zegbee Dengan Topologi Cluster Tree. Jurnal Teknik Elektro ITP ISSN 2252-3472, 3(1), 19-27. 
Wahyudi, E., Hidayat, R., \& Sumaryono, S. (2012). Unjukkerja Standar ZigBee pada WPAN dengan Topologi Mesh. Jurnal Nasional Teknik Elektro Dan Teknologi Informasi, 1(2), 40-47.

Yulianto, D., Jazi Eko, I., Kirbani, S. B., \& others. (2012). Model Deteksi Sistem Peringatan Dini Aktivitas Gunungapi semeru dengan Jaringan Sensor Nirkabel Terintegrasi. Retrieved from http://repository.ugm.ac.id/96945/ 